\title{
A Contribution to our Knowledge of the Ovary and Intra-ovarian Egg in Teleosteans.
}

\author{
By \\ w. L. Calderwood, \\ Director of the Laboratory of the Marine Biological Association. \\ With Plates XI and XII.
}

The reproductive organs of Teleosteans have been studied by many writers. All observations, however, appear to be either on the organ as seen at only one season of the year, or on the early maturation of the ovum and development of the embryo. I do not in this paper concern myself with the primitive development of the ovary, or the subsequent growth of the permanent ova from the primitive ova or sexual cells of the embryo (1). My attention is rather centred on the adult and mature organ in its various conditions of sexual activity or repose.

I have preserved and sectioned a series of ripening ovaries, and have also turned my attention to the spent organ, and the manner in which it again reaches the condition of what is sometimes known as sexual inactivity ; in this way completing what I may call the adult ovarian cycle.

I have examined the ovaries of the following species:-Pleuronectes limanda, Trigla lyra, Trigla limanda, Labrax lupus, Lophius piscatorius, Clupea finta, Ammodytes tobianes, Gadus rglifinus, Solea vulgaris, Conger vulgaris, and Merluccius vulgaris.

My most complete series of sections are of the ovaries of the common dab (Pleuronectes limanda) and hake (Merluccius vulgaris), forms readily procurable at Plymouth. The main results of this paper are, therefore, drawn from the examination of these species, sections from the ovaries of the others being used for comparison.

Since the ovary is modified to suit the requirements of the 
ova, and affected according as the principal ova are ripe or unripe, it will be convenient to consider the ova first.

\section{The Ova.-General.}

All writers on the intra-ovarian condition observe large and small eggs in ovaries of fishes which are in any way approaching ripeness.

Scharff (2) treats in one chapter on the small ova, in another on the large.

My observations incline me to consider that three conditions must be noticed for fishes, as has been done in the case of batrachians, since it seems more than probable that, in all ripening ovaries, ova for three consecutive spawning periods are present. I therefore propose to treat of the ova under the names of great, small, and minute.

The condition is very well seen in sections from the unripe ovary of a haddock, where the small ova are about the size of the nuclei of the great, and the minute are gathered together in clusters, and are individually by no means so large as the nuclei of the small ova.

So far as I can ascertain, the organ in its flaccid or spent condition has not been previously investigated. Very considerable difficulty has been experienced in obtaining good preservations of spent ovaries, the semi-fluid contents and general disintegration of parts rendering very great care necessary. By removing the organ in situ into the fixing reagents it has, however, been possible to obtain sections showing what I believe to be accurate representations of the organ in this condition.

Scharff, in his paper already referred to (2), described the smallest ova in the haddock (Gadus aglifinus), and what he terms the next stage in the gurnard (Trigla gurnardus). These two stages, so far as I can determine, are not stages in the development of one season's eggs, but represent ova which will be extruded at two distinct spawning periods. The larger egg's of his second stage represent, in fact, the formation of great ova at the completion of a spawning season.

The material collected for his excellent paper was preserved in the summer, the only time when this condition can be seen.

I am also led to this conclusion by his description of the eggs themselves.

They show a circular division of the protoplasm into two distinct zones, the inner of the two surrounding the nucleus being more granular, and in section much more darkly stained than the outer; while the nucleus has its membrane, chromatic substance, 
and nucleoli. When the ova are in this condition the ovary is in process of being reconstructed. With the process of spawning the lamellæ have been ruptured and the stroma scattered. With the inward growth of the supporting tissue which will be treated of later, the eggs which are at a future period to follow those which have already been extruded are being collected into new lamellæ. The flaccid and utterly empty condition of the ovary, as seen in the sections of the spent organ, has to be overcome. By means of a fairly complete series of slides I have been able to follow through this stage, and conclude that this condition of protoplasmic separation in the ovum has a significance not so much connected with the development of the ovum itself as with the building up of the trabeculæ of the ovary.

A circular separation of the protoplasm in the egg of fishes has been noticed by Eimer (3) as far back as 1872, and a similar arrangement has been commented upon in reptiles, molluses, and insects by other authors. To account for it various suggestions have been made. The dark ring must either take its peculiar property from some outside tissue, or stain darkly because it has received matter from the nucleus. Will, in treating of Orthoptera, (4) describes the disappearance of the nuclear membrane and the migration of nucleoli to the surface of the ovum, forming in this way a follicular epithelium. Scharff also (loc. cit.) notices the presence of a few nucleoli outside the nuclear membrane of Gadus virens, and assigns the peculiar property of this darkly stained layer to the presence of nuclear substance.

The clear protoplasmic portion seems to have attracted less attention, and to be generally considered as the normal unchanged protoplasm of the egg. So far as I know, the ultimate history of the clear and dark layers has not been traced to its issue.

In sections treated in the usual way the dark portion often becomes rather opaque for good observation, the staining having a distinct resemblance to that seen in the colouring of nucleoli. Nevertheless at this particular stage I have not, in the common dab, been able to detect the presence of nucleoli outside the nuclear membrane, although those bodies have been sufficiently apparent in this position at other stages. Scharff says that he saw these nucleoli occasionally in the dark layer, but never, except in the case of Hippoglossoides, at the surface of the egg. The explanation may probably be that in different species the nucleoli are given off at different times, and that in the case of the common dab this process takes place previous to the differentiation of the areas. I find that the light protoplasm soon splits off from the dark.

Fig. 1 shows this process. The egg seems to increase rapidly in 
circumference, owing to the extension of the light protoplasm alone, while the dark protoplasm and nucleus remain as before. A condition is presently reached where this extension causes the light to separate from the dark, so that a cavity is formed around the dark centre with its contained nucleus, $i$. $e$. around what must now be considered as a complete ovum in itself. The light protoplasm then appears to diminish in extent until only a margin is left inside of what was the old investing membrane.

The cast-off membranes of neighbouring eggs coming in contact with each other, and the light protoplasm being almost completely absorbed, the appearance becomes that of trabeculæ, The contained spaces are occupied by the ova, and the interstices become filled up by fresh ova of a small size, formed from epithelial cells in a manner to be described at a later stage.

\section{The Great Ova, or those which are to be extruded at the first} spawning period.

In the ovary of a common dab which is approaching ripeness (fig. 2) the large ova are well marked. The zona radiata has thickened, and the protoplasm of the egg shows a distinctly reticulated structure. The nuclear membrane has disappeared, the nucleus now appearing as a clear area, either surrounded by or scattered over with the numerous nucleoli, occupying an eccentric position in the ovum.

The nucleoli are much more circular in shape than is the case in eggs of an earlier stage, and when they are arranged round the periphery of the clear area there are numerous very minute bodies of exactly the same appearance to be found in the area itself. These minute bodies must also be considered as nucleoli, for from an examination with a very high power I find that they are budded off from the large nucleoli at the margin of the clear area, and then travel inwards towards the centre. Fig. 3 is drawn from an ovum in the same section as is represented by fig. 2 , and sufficiently represents the appearance indicated. These small bodies, by enlarging, form another condition of the nucleus seen at this stage. The parent nucleoli seem to give off many buds in this way, until, having lost much of their old constitution, they stain feebly, and are difficult to distinguish from the coarser granules of surrounding protoplasm.

There is, therefore, among Teleosteans a more or less distinct congregation of nucleoli in the centre of the degenerating nucleus, similar to that described by Iwakawa (5) in the egg of Triton at a different stage. This author concludes that the nucleoli, or, as 
he terms them, the "germinal dots," move to the centre and divide up.

I am inclined to think that in the case of Teleosteans the greatest amount of division takes place at the surface of the nucleus, and that many of the parent nucleoli afterwards become absorbed in the encroaching protoplasm. In this case the darkly stained protoplasmic ring spoken of above is in part explained.

The vacuolated condition present in the nucleoli of Triton during their division, and also described by $\mathrm{O}$. Hertwig (6) in the egg of Hæmopsis and Rana, and by V. la Valette St. George (7) in the egg of Libellula, is not present ; nor is there any concentration of these division products into a mass in the centre of the nucleus. A vesicular condition, however, which might be mistaken for vacuolation, appears, and is described below in the case of the conger.

The surrounding protoplasm continues to encroach on the space of the former nucleus, and the central nucleoli appear to be ultimately enveloped in this condition. They then correspond to the permanent nucleus of the ripe ovum as described by Hertwig in Toxopneustes.

In the ovary which is quite unripe, in distinguishing the three generations of eggs, many intermediate stages leading from the one to the other are at the same time noticeable. The largest of the eggs in the common dab of this stage do not measure more than four fifths of a millimetre. The nucleus of these eggs has a distinct membrane, and the nucleoli are arranged in contact with its inner surface, so that in section they appear in a ring inside the membrane-the usual appearance of nucleoli in fish eggs. The ova at this stage do not present so marked a contrast as they do later, the proportions between the sizes being less.

The ovary of the common dab may be found in this unripe condition all through the autumn and winter months; it is, therefore, the condition which has been often noticed. About two months before spawning takes place the great ova, which will be ripe for the first spawning season, show signs of rapid enlargement, and in a comparatively short time assume the appearance seen in fig. 2, already described.

I have made no direct observations on the origin of the micropyle, and will pass over the egg in the ripe extruded condition. It has been noticed (8) on more than one occasion along with the ova of other Pleuronectids (9).

I shall rather take up the consideration of the ovary after the act of spawning. Great ova are then still present in limited numbers. I have counted thè number visible in several transverse sections, and find that there are from ten to fifteen seen in each section. It 
is well known that in many Teleosteans all the eggs are not shed at once, but are rather got rid of a few at a time, brief intervals occurring between each extrusion. In sections of spent ovaries the first thing which strikes one is that the remaining great ova are in many cases provided with a complete nucleus with its surrounding membrane, and nucleoli arranged round the periphery, just as is seen in the egg before it is ripe.*

The majority of the ova, however, either show the after condition in which the nuclear membrane has vanished and the nucleoli are collected towards the centre, or they are in the condition of having no nuclei at all, and are advanced in the process of disintegration. When in this last condition they present a vacuoled and atrophied appearance, seen in fig. 4, where an ovum with nucleoli still present, although the outer protoplasm of the egg is beginning to show signs of decay, is also seen. The eggs still presenting the nucleated appearance are a few which, in my estimation, have never become quite ripe ; and, from the appearance of the ovary before spawning takes place, I am inclined to think that a few must be extruded in this condition. One does, in fact, generally notice that when fertilizing by artificial means a quantity of spawn, there are some which seem impervious to the action of the spermatozoa.

The eggs left in the spent ovary become opaque, and can readily be noticed in the fresh organ on this account. They are present for a considerable time after spawning is over.

The small nucleoli, budded off in the manner already mentioned, eventually appear to become free in the loose débris of the spent organ by the total disintegration of the protoplasm around them. The progressive history of the nucleoli can be seen very well in the conger, because these bodies are of specially large size. In studying this form the usual appearance is seen to be granular, but in some instances the granules are arranged in the form of a circle placed eccentrically, as seen in fig. 5. As the egg approaches ripeness, however, I find some interesting appearances. While the nucleus has yet a distinct membrane, and the nucleoli are oval in outline-the long axis being placed in a radial manner-a clear highly refracting band appears across the short axis. This band becomes spherical, and increases in size till the granular substance of the nucleoli is collected only at the two poles. I notice, however, that the inner pole has always more granular matter than the outer. These vesicular bodies have a distinct double contour, and are of a somewhat smoky colour even in stained sections. Their growth is towards the nuclear membrane, and eventually, when this

* In one instance I observed that a large nucleolus was about to give off four small circular nucleoli, showing that the progressive development had not yet ceased.

NEW SERIES.-VOL. II, NO. IV. 
membrane begins to disappear, they burst through, forcing in each case a small amount of nucleolar substance in front of them-the outer pole of the nucleolus. They then take up a position amongst the surrounding yolk-spheres. The nucleolar portion which is thrown off does not assume any definite shape, but rather becomes loosely interspersed amongst the yolk-spheres. It still stains readily. Unfortunately, up to the present date no observer has been able to obtain the ripe egg of the conger. I am on this account unable to make any definite statement as to what becomes of the vesicles just described. I can only throw out the suggestion that there is probably some connection between these vesicles and the oil-globules. The supposition is based simply on the striking resemblance which the vesicles have to oil-globules, and on the absence of any theory which accounts for the existence of the globules in any other way.

Scharff (loc. cit.) mentions clear vesicles with granular nucleolar contents as being budded off in Trigla, but supposes that the vesicles are formed in the nuclear substance itself. The ovum of Trigla has a large oil-globule, or it may be two or three small ones (the last case being rare). Should the vesicles described by Scharff prove to be analogous to those I have just described, a still greater probability will be given to my suggestion. Personally I am inclined to think that the vesicles are analogous, although not noticed by Scharff as coming from the nucleoli. I have not met with any other products of the nucleoli, such as the tubular prolongations described by Balbiani (10) in Geophilus. When the nuclear membrane has disappeared the nucleoli have given off so many of these spheres, and have themselves taken up a position so far back from where the nuclear membrane originally was-partly, no doubt, on account of their outer poles having been carried away - that the space of the nucleus has become small and irregular. Since, as I have already said, it is extremely difficult to procure a ripe conger, I have not in this species been able to follow through the so-called disappearance of the nucleus.

\section{The Small Ova.}

In fig. 4, which has already been referred to, the three classes of ova are distinctly seen.

To study the small ova from their very commencement, one should begin at the point where the small ova are for the first time distinguishable from the minute, $i . e$. when the ovary is in a quite unripe condition, a year and a half probably before the small ova will be extruded; but since the small ova show no change till the time when the great ova have to be discharged, the early period may be passed over. 
My account of the small ova, therefore, simply becomes one of their transformation into great ova at the time when the latter are extruded.

In the spent ovary, then, where a few great ova still remain, the small ova of the past year are seen to present two distinct appearances ; one that of fig. 4, the normal, and another a much-vacuoled condition, seen in fig. 7 . In both I find signs that the ova do at this stage divide. I have chosen figs. 7 and 8 to represent this, both being taken from the same section. There is a considerable amount of variation in the sizes of the eggs of each condition, but from a series of careful measurements I do not distinguish any difference between the average sizes of sufficient importance to be worthy of mention as of significance. It will be noticed from the figures that the nonvacuoled ova have the nucleus with its nucleoli present in the ordinary position, whereas in the vacuoled eggs the nuclear membrane has no nucleoli in connection with its inner surface. I have examined a large number of slides showing ova in this condition, but only on one occasion have I found a slight trace of nucleoli. They appear in the normal position, but are extremely small in size, and have apparently atrophied. In a few eggs, which show what I may perhaps describe as an inclination to become vacuoled, the nuclei are already considerably reduced. I further notice that for the most part the vacuoled eggs lie at the surface of the ovary, the normal or fully nucleated eggs being towards the centre in the vicinity of the germinal epithelium. I am convinced that the vacuoled eggs break up simultaneously with the few remaining great ova. There is probably a double significance of this curious condition. The fact that a limited number of great, and very many small eggs should break up at the same time may go to show that the old eggs are not present in the spent ovary, simply because they could not be extruded, but because they may be useful as pabulum, and that there are a superabundance of small eggs formed from the epithelium at an early stage. It is somewhat difficult to estimate with any degree of accuracy the number of eggs present in an unripe section, although in the case of the riper organ there may be less difficulty. Numbers no doubt vary in different individuals; but it seems probable that even with the great enlargement of the organ and the filling up of the central cavity in ripening ovaries there is not room enough, after the great eggs are gone, for a sufficient number of new developing minute ova. At this stage, at any rate, the débris of the organ is added to by the breaking up of a certain number of the ova under consideration, and I take it that the products must either be used for the nourishment of the coming stroma, or are gradually got rid of by extrusion. In the normal eggs of this stage 
the nucleoli are few in number but large in size. Whenever the nucleoli atrophy and disappear there is no prospect of the egg ever coming to maturity. Without nucleoli it cannot even form its dark ring of protoplasm. It seems to me that under these circumstances I cannot agree with Scharff and Will, who unite in attaching no morphological significance to the nucleoli.

It is true, as the former says, that they are sometimes present and sometimes entirely absent, but I have never found any evidence to show that without nucleoli ova of Teleosts can ripen. I am, in fact, inclined to regard the nucleoli as of the highest importance, the fountain-head of the entire system.

\section{The Minute Ova.}

The only point of interest in studying the minute ova is their origin, since their average condition is one of inactivity.

After spawning, the enveloping membrane of the ovary sends out fibrous prolongations in an irregular manner towards the centre of the organ. These form leading lines of support in the loose arrangement of the ova. As offshoots from these the supports of the lamellæ are formed. In different species the lamellæ run in different ways, e.g. longitudinally in Pleuronectids, transversely in Gadidæ, and obliquely in the mackerel. With few exceptions (Murænidæ and Salmonidæ) the inner boundary line of the lamellæ is composed of germinal epithelium.

It has been stated by Brock (11) and Kolessnikov (12) that each forming ovum is produced from one single epithelial cell. In addition to this the appearances presented in my sections lead me to believe that, in the case of the common dab at any rate, ova are also formed in another manner. I find small nests of cells, collected at intervals, inside the germinal epithelium, and from watching them am satisfied that while perhaps in the majority of instances ova are formed from single cells only, they are also formed from these nests of, it may be, ten or twelve cells. Fig. 9 shows a growing lamella at this stage, where a few of the nests are seen $(n)$. They are quite separate from all other epithelial cells, and shortly begin to show a disposition to coalesce. The outlines of the individual cells disappear, and the mass, beginning to stain deeply, assumes a very dense appearance.

A collection of deeply stained bodies, very similar to the nuclei of the cells or the amalgamated nuclei, then make their appearance, and take up the position of nucleoli in what must now be called the ovum. Meanwhile there are other epithelial cells collecting in all the spaces of the ovary-often showing division. These grow round 
the forming ova, and ultimately form the follicle. I find no sign of a central cell in the nest, enlarging at the expense of the others, becoming itself the ovum while the rest form the follicle. These nests of epithelial cells which become ova have a singular resemblance to the nests described by Balfour (loc. cit.) for Elasmobranchs. In his description of the formation of the permanent ova several primitive ova coalesce to form nests, masses, or syncytii. These nests enlarge in size as development proceeds-explained by the probable division of nuclei without a corresponding division of the protoplasmic matrix, so that nuclei become very numerous. Some of the nuclei unite and become the nuclei of permanent ova, and are budded off with their surrounding protoplasm, which is of small amount; others again break up, and are used as pabulum for the young ova. "In many cases normal nuclei of the germinal epithelium may be observed within the ovum." The ova then become surrounded by germinal epithelium, from which the follicle is formed. If in the common dab we call the epithelial cells primitive ova, the analogy is practically complete.

My study of the egg membranes themselves is of course confined strictly to those of intra-ovarian ova. I may preface the few statements I have to make by explaining that I accept the term " zona radiata" as used by Balfour and some others in describing the constant and most important membrane, and find it convenient to treat of other membranes as inside or outside, according to their position with regard to that membrane. What I shall call the zona radiata is, therefore, the vitelline membrane of Waldeyer, Kölliker, and others ; the egg capsule of His and Müller; and the zona pellucida of Eimer.

Cunningham (13) describes the almost ripe ovum in the sole when the radial striæ are very distinct. The vitelline membrane (zona radiata) described by him is considered to be the only membrane present. My examination of soles' ova inclines me to the conclusion that there is a membrane inside the zona radiata, as well as the follicular layer outside. The membrane is seen to best advantage in eggs in which some slight shrinkage of the protoplasm has taken place, and fig. 10 represents the appearance as seen in an egg of this description. Scharff figures an exactly similar condition in the egg of Trigla, and other authors have also described it. Kupffer, when treating on the herring, compared this structure to the true vitelline membrane. Ransom calls it the inner yolk-sachis outer yolk-sac being the zona radiata of Balfour. On the other hand, His, Waldeyer, and Brock deny its existence.

The membrane may be the product of the vitellus, or it may be derived from the zona radiata, and it is also possible that the zona 
may be derived from it. The ready way in which it seems, by clinging to the yolk mass, to separate from the zona radiata, appears to favour the idea that it has no immediate relation with the latter. In this case it may be possible that, in those species in which the membrane is present, no pabulum can be supplied to the ovum from the follicular layer through the supposed radial pores. I cannot prove the origin of this structure, and therefore hesitate to give it the name of vitelline membrane. It has a very distinct double contour, and appears to be proof against stain.

What becomes of it when the ovum is shed and comes in contact with the water I am, unfortunately, unable to say. Its relation to the perivitelline space would be a point of some interest; and further, if this space contains albumen, as stated some time ago by Raffaele, and not water which has gained access through the micropyle or radial canals, a somewhat important function might be found for it.

In none of my sections do I find a membrane outside of the zona radiata. The follicular layer is often irregular in its composition, and sometimes cloudy in appearance, and a distinction between it and any outer layer of the zona radiata, therefore, would be difficult. I am inclined to think, however, that an outside membrane of this kind must occur in very few species (14). Brook (15) describes a vitelline membrane outside of the zone radiata in Trachinus vipera, and Balfour (16) notes one in the herring and describes an imperfect one in the perch, but so far as I know these are the only instances.

\section{The Ovary.}

In treating of the whole organ I do not intend that my remarks should apply to the ovaries which, according to Jules MacLeod (17), constitute "la première forme" - the ovaries of Salmonidæ and Murænidæ, where the ova are dropped into the abdominal cavity, and find their way to the exterior by abdominal pores. In the case of these fishes the arrangement of the ovary is, to a certain extent, reversed, the germinal epithelium being free, and not enclosed, so as to form a tube, by a surrounding membrane.

Although I have described the nucleoli of the conger's egg, I shall therefore not touch on its ovary, but must refer the reader to the account given by Cunningham (18). I shall confine my remarks to the ovaries of those fishes in which the epithelium is enclosed by a surrounding membrane, and the eggs, becoming free in the centre of the organ, are extruded through an oviduct.

The ovary is usually described as a tubular structure, and in the 
unripe condition it is so; but as development of the ova proceeds, the lumen becomes more and more closed by the extension of the lamellæ towards the centre of the organ.

At the time when a section shows an appearance similar to that shown in fig. 2 the lumen disappears, and the lamellæ become indistinguishable on account of their closely packed and fused condition. Ultimately, by the thinning out and rupture of the epithelium, the almost ripe ova lie free in the organ, ready for extrusion.

The outer wall consists of fibrous tissue, which assumes different appearances according to the sexual condition of the ova. The fibres run, for the most part, in a longitudinal direction, and are therefore seen best in longitudinal sections. The outer fasciuli, however, frequently bend until they lie transversely. From the main membrane, offshoots spring towards the interior of the organ. These pass off in a curved manner, similar to the spokes of an iris diaphragm, although by no means so regularly.

The offshoots form the leading divisions of the internal arrangement, and on their branching afford support to the lamellæ in much the same way as veins do in the leaves of plants.

In what we may describe as the resting stage in the common dab-for I certainly believe that a condition of this sort obtains -when after spawning the ovary has been made up with quite unripe eggs, the outer wall has a thickness of about $\cdot 9 \mathrm{~mm}$.

In following the various conditions of the ovary we find that the condition of its outer wall fluctuates in a rather singular manner, that in the cycle from one resting stage to another it thickens twice, and thins again twice. From the $\cdot 9 \mathrm{~mm}$. thickness it gradually grows until, when the ova are what has been described as half ripe (fig. 2), (when the lumen of the ovary disappears) it reaches the thickness of from $\cdot 19$ to $\cdot 20 \mathrm{~mm}$. This is its maximum thickness in the purely laminated fibrous condition. The organ now increases rapidly in size, and as it does so the outer wall decreases in thickness, the fibrous composition being less and less evident as this goes on. When the ova are ripe the thickness is only from $\cdot 2$ to $\cdot 3 \mathrm{~mm}$. in the common dab.

Whenever the process of spawning releases the pressure, the wall rapidly thickens again, and when spawning is completed and the organ is in its flaccid condition, a distinct division into an outer and an inner layer is noticeable. The outer is still the normal fibrous envelope, but the inner coat becomes highly modified. Numerous nuclei make their appearance (fig. 11), and increasing by a process of division, first of all form thickened masses, and then by the bursting of the inner membrane are poured out, and form irregular masses amongst the vacuoled eggs at the periphery of the ovary. 
It is to be noticed, however, that the thickened masses occur round the inner surface of the membrane only at intervals, and that the modified inner portion becomes decidedly thin at the other parts. One of the thickened masses is seen in fig. 12, the total thickness in this case being $\cdot 25 \mathrm{~mm}$. Following the progress of the masses, we find that the cells thus added to the stroma continue for some time to keep together, and that those on the inner margin continue to divide rapidly, extending inwards amongst the loosely arranged ova. They often give off chains of cells which follow separate directions, twine round ova, and extend until they eventually reach the germinal epithelium. We find, in short, that the whole supporting structure of the ovary has been laid down.

These chains of cells then begin to flatten, they stain more and more deeply, the nuclei become less distinct, and the appearance becomes once more that of ordinary fibrous connective tissue.

The spaces between the fasciculi of fibrous tissue are generally considered to contain albuminous matter, and therefore with the rupture of these cells from the ovarian membrane an albuminous substance would at the same time be given to the ovary. Such a substance has been described as being present in the ovaries of Teleosts, its function being considered to be that of a lubricant, useful in allowing the eggs to be readily extruded at the spawning period. The origin of this substance may be explained in this way.

In treating on the great ova in the common dab I have stated that the quite unripe condition persists all through the autumn and winter months, that the ovary is then in a resting or inactive condition.

I am not prepared to consider this statement as applicable to all Teleosts, because in some cases, if a resting period does occur, it must be a short one. I am not even prepared to say that all Pleuronectids have a distinct resting period, because the reproductive organs of this genus, as of others, show a considerable diversity of arrangement, and the spawning periods are often widely apart. Still the condition seems also to obtain in round fishes, since I find it in the hake. A circumstance which may affect the condition very decidedly is the extent of time taken by any one species in getting rid of all its spawn. If the intervals between the expulsion of successive batches of ova are prolonged, then it follows that the anterior part of the ovary is very much later in getting into its resting condition, and that by the time it has done so a progressive change may have already set in at the periphery of the posterior or early part of the organ.

The Plaice, for instance, has a spawning period which extends over a very considerable length of time, and it also sheds a large 
number of eggs in each batch-an interesting provision, by which a fish possessing somewhat bulky eggs can nevertheless extrude an unusually large number, since when all the eggs of the various batches have escaped, many more have swelled to maturity than could possibly have been contained in the ovary if all had to be shed at once, or the batches soon after one another. It seems to me, therefore, that with this condition a resting period must of necessity be at any rate much shorter than in the condition where batches of ova are rapidly extruded one after the other, until all are gone.

I should, therefore, expect that in all Salmonidæ, and fish which get rid of all their eggs at once, a long resting period was invariable. The common dab certainly does not get rid of all its eggs at once, yet has a long resting period; and if similar conditions bring about similar results in other groups, I can have no hesitation in saying that I believe a resting period is usual in Teleosts.

It may appear that I lay too much stress on this point, but with the diversity of systems of extruding the eggs, the long period during which spawning goes on, and the presence of eggs of more than one generation in the ovary, a resting period has appeared to some to be improbable.

Whenever the ova escape and the pressure on the ovary is relieved, the fibrous walls contract rapidly; and as the organ becomes empty, so it is drawn together from every point. The majority of fibres were seen to run longitudinally; the significance of this now appears, since the greatest reduction in size takes place in the long axis of the organ.

From the very greatest distension the ovary is speedily reduced to a size almost as small as that seen in the immature condition, the walls being then at their very thickest.

It was my original intention, in treating of the ovary, to compare the immature organ of the young fish with the resting or inactive condition in the adult; being of opinion that a decided difference could be demonstrated - a point of very decided importance. I have, however, decided against taking the matter up in this paper, since, if the subject is treated from a practical fishery point of view, the results can be more forcibly applied to that branch of work, on which it has the most important bearing. 


\section{Literature.}

1. BALFour, F. M.-Structure and Development of the Vertebrate Ovary, Quart. Journ. Micr. Sci., xviii, p. 383.

2. SoHARFF, R.-On the Intra-ovarian Egg of some Osseous Fishes, Quart. Journ. Micr. Sci., August, 1887.

3. EnMer.-Archiv für mikr. Anat., vol, iii.

4. WiLL, L.-Bildungsgesch. und morphol. Werth des Eies von Hepa cinerea $u$. Notonecta glauca, Zeitschrift für wiss. Zoologie, xli, 1885.

5. Imakawa, T.-The Genesis of the Egg in Triton, Quart. Journ. Micr. Sci, xxii, 1882, p. 260.

6. Hertwig, O.-Beiträge z. Kenntniss d. Bildung, Befrachtung, u. Thier-lung d. ThierEies, Morphol. Jahrbuch, vol. iii, 1877.

7. V. ua Vauetre, St. George.--Ueber d. Keimfleck u. d. Dentung d. Eithiele, Arch. f. Mikr. Anat., ii, 1866.

8. Cunningham, J. T.-Eggs and Larve of Teleosts, Trans. Roy. Soc. Edinb., xxxiii, pt. 1, p. 97.

9. MoIntosh, W. C., and Prince, E. E.-On the Development and Life Histories of the Teleostean Food and other Fishes, Trans. Roy. Soc. Edinb., xxxv, pt. 3.

10. Balbiani, E. G.-Sur l'origine des cellules du follicule et du noyau vitellin de l'œuf chez les Géophiles, Zool. Anzeiger, 1883.

11. Brock.-Beiträge z. Anat. u. Hist. d. Geschlecht-Organe d. Knockenfische, Morphol. Jahrbuch, iv, 1878.

12. Kolessnikov.-Ueber d. Eientwickelung bei Batrachiern und Knockenfischen, Arch. f. mikr. Anat., xv, 1878.

13. Cunningham, J. T.-A Treatise on the Common Sole, Marine Biological Association, Plymouth, 1890.

14. BRook, G.-The Formation of the Germinal Layers in Teleostei, Trans. Roy. Soc. Edinb., 1886.

15. Brook, G.-Preliminary Account of the Development of the Lesser Weaver-fish (Trachinus vipera), Proc. Linnean Soc. Lond., Zoology, xviii, 1884.

16. Balfour, F. M.-Comparative Embryology, vol. i, p. 50.

17. MacLeod, Jules.-Recherches sur la structure et le développement de l'appareil reproducteur femelle des Téléostéens, Archives de Biologie, ii, 1881.

18. Cunningham, J. T.-On the Reproduction and Development of the Conger, Journ. of the Marine Biol. Assoc., ii, No. 1. 
Fig. 1.

Plate XI.
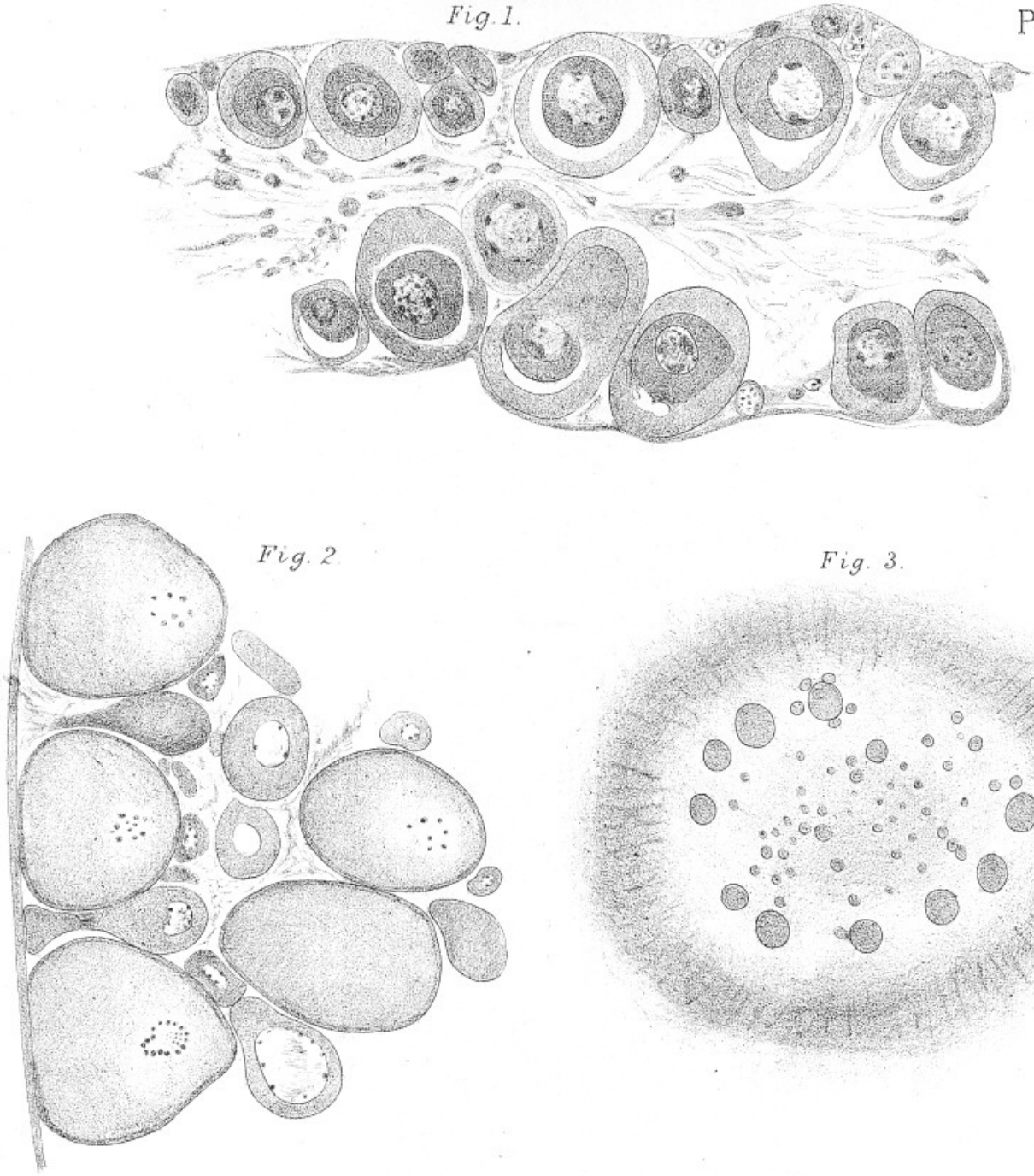

Fig. 3

Fig. 4 .
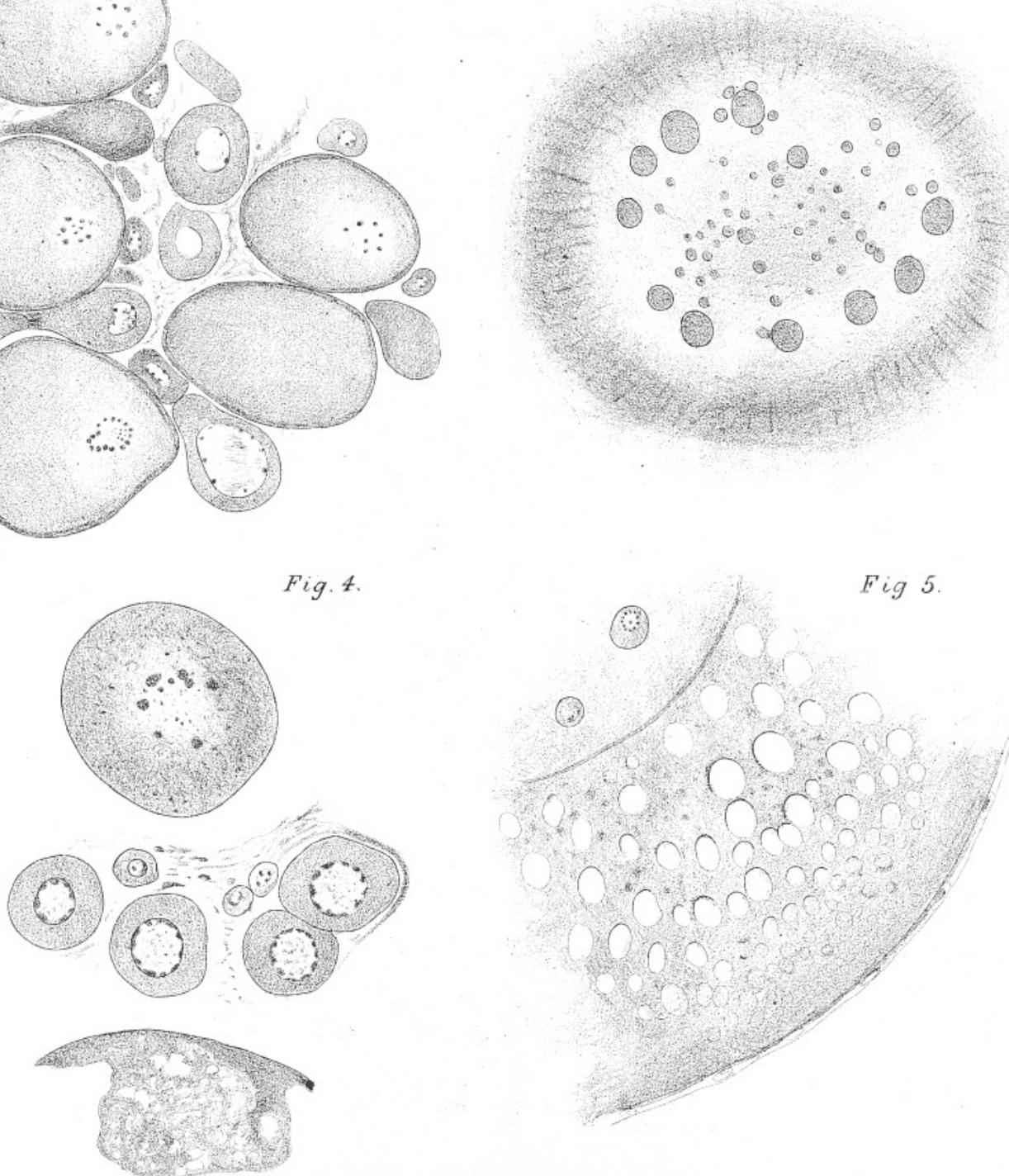

Fig. 6.

Plate XII.
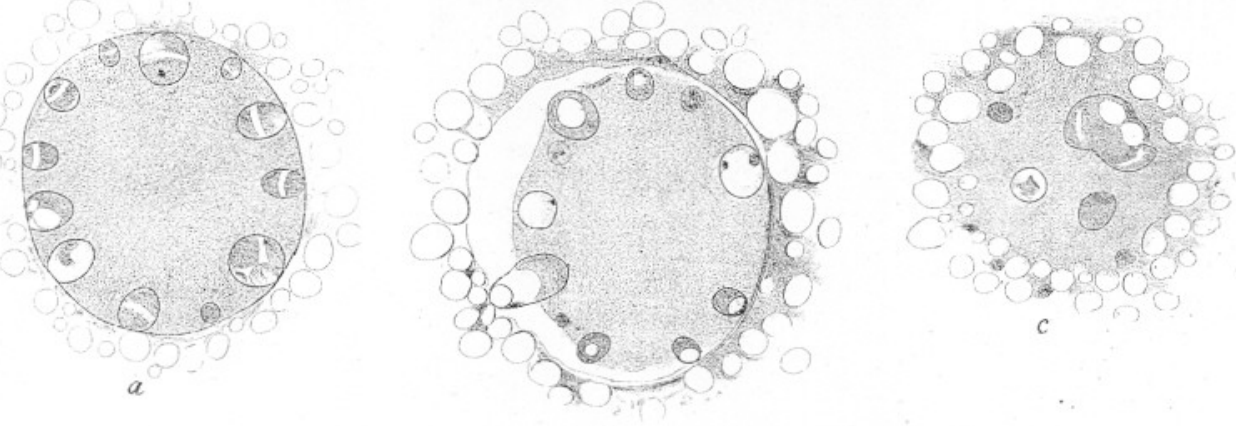

Fig. 7.
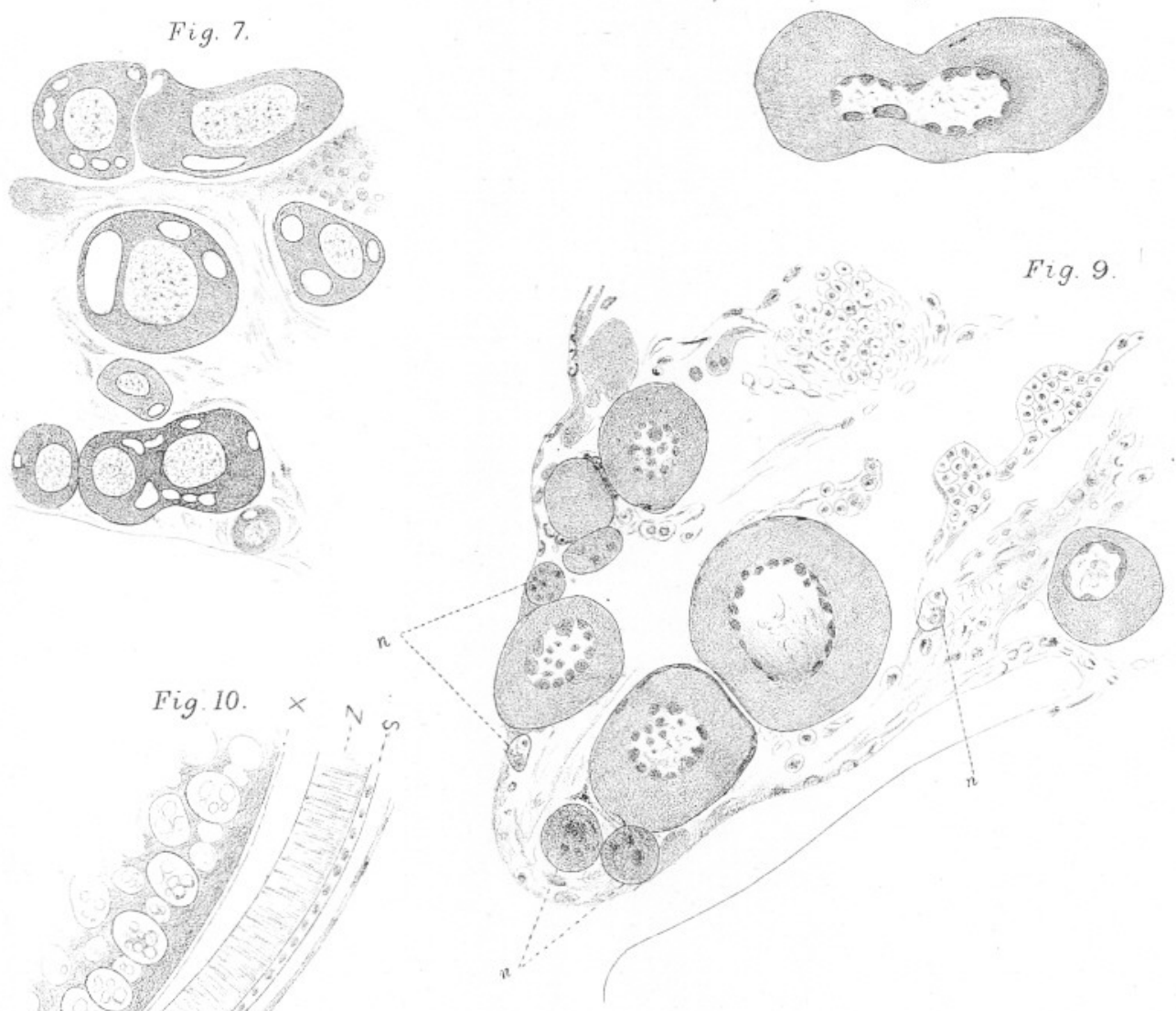

Fig.ll.

Fig. $10 . \times N$

$$
\text { b }
$$

Fig. 8.

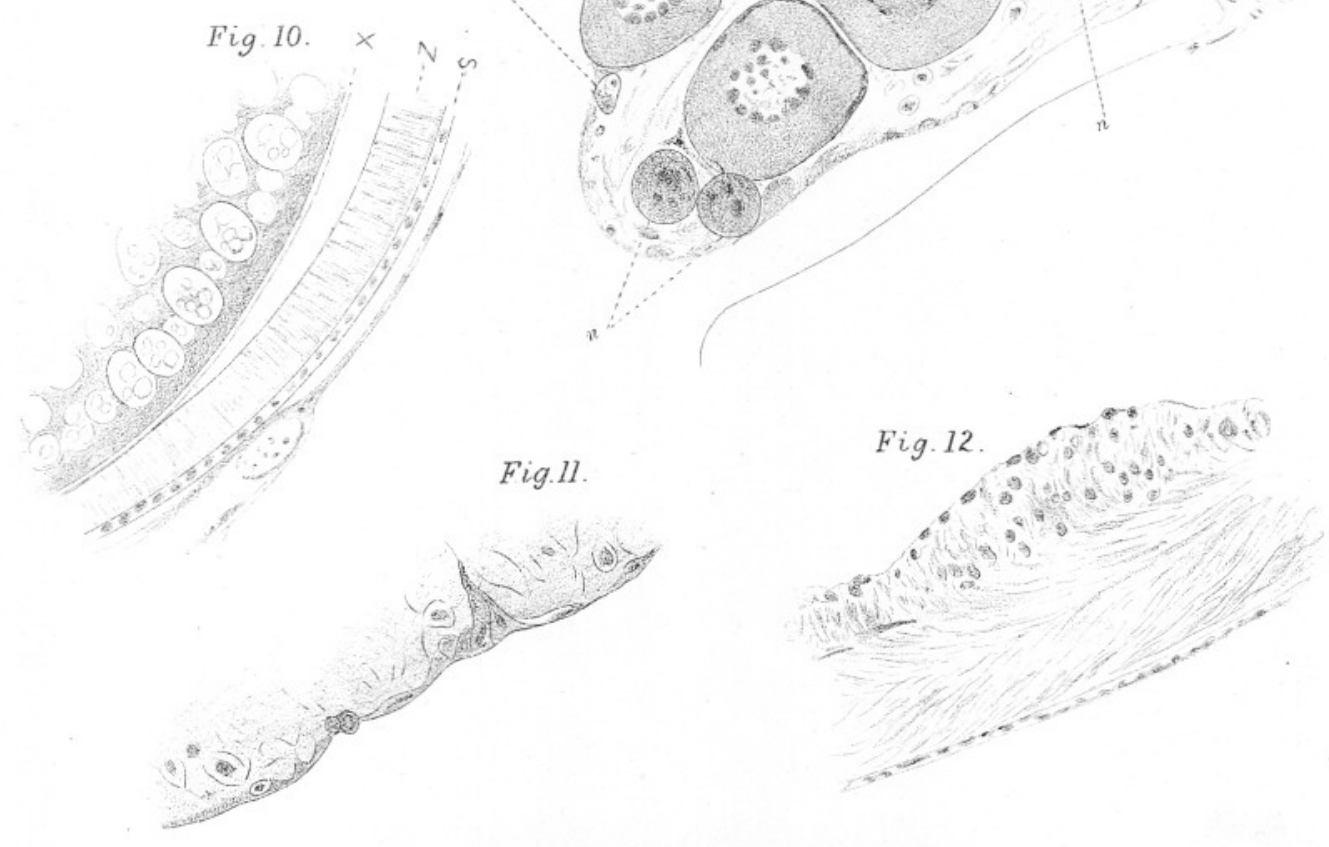





\title{
DESCRIPTION OF PLATES XI AND XII.
}

\author{
Illustrating Mr. Calderwood's paper on "A Contribution to our \\ Knowledge of the Ovary and Intra-ovarian Egg in Teleos- \\ teans."
}

\section{PLATE XI.}

FIG. 1.-Forming lamella of common dab, showing the ova separated into darkly stained and light zones, and the subsequent splitting of the light zone from the dark. Young ova developing from epithelial cells are seen filling up the remaining spaces of the lamelia. Zeiss D, oc. 2.

FIG. 2.-Transverse section of ovary of common dab becoming ripe, showing the three sizes of ova, the great having no nuclear membrane, and the rapidly thinning ovarian wall. Zeiss CC, oc. 2.

Fic. 3.-Highly magnified nucleus of egg taken from same section as Fig. 2, showing absence of nuclear membrane and budding nucleoli. Zeiss $\mathrm{F}$ cor., oc. 4.

Fig. 4.-Portion of section from spent ovary of common dab, showing the three sizes of ova, large egg still with nucleoli although zona radiata disappeared; also portion of egg in advanced state of disintegration.

FIG. 5.-Transverse section of intra-ovarian ovum of conger becoming ripe. Nucleoli with circular arrangement of granules.

\section{PLATE XII.}

FIG. 6, $a, b, c$.-Three successive stages in the development of nucleus in ripening conger. $a$. Nuclear membrane distinct; nucleoli arranged regularly, numerous, showing clear bands across short axis. $b$. Showing ultimate development of clear bands into vesicles, which are expelled from the nucleoli, and merge with the yolk-spherules. $c$. Nuclear membrane gone; protoplasm encroaching on former space of nucleus; nucleoli few ; vesicles still forming; nucleolar matter seen outside area. Zeiss F cor., oc. 2.

FIG. 7.-Vacuoled small ova without nucleoli dividing, taken from margin of longitudinal section of spent ovary of common dab. Zeiss F cor., oc. 2.

Fig. 8.-From same section as Fig. 7. Ovum from centre of spent ovary of common dab. Nucleoli present; ovum showing signs of division. Zeiss F cor., oc. 2.

FIG. 9.-A longitudinal section of lamella of ovary from common dab in process of being built up after spawning. It is a later condition than that seen in Fig. 4. The germinal epithelium is rapidly forming minute ova, and the follicular layer of the larger eggs is also appearing. The small masses of epithelial cells also forming minute ova are seen in various stages of development at $n$.

FIG. 10.-Section showing the egg-membranes in the almost ripe ovum of the sole. $\mathrm{s}=$ follicular layer. $\mathrm{z}=$ zona radiata. $\mathrm{x}=$ the inner membrane described by Kupffer as the vitelline membrane.

FIG. 11.-Inner surface of fibrous envelope of spent ovary, showing the first appearance of the connective-tissue cells. Zeiss F cor., oc. 2.

FIG. 12,-Later stage in the development of connective-tissue cells on the inner surface of ovarian envelope, showing a collection of the cells into a mass previous to their separation from the fibrous portion of the wall. Zeiss D, oc. 2 . 